\title{
KEMAMPUAN KONSENTRASI PASTA GIGI DALAM MEMBUNUH KECOA AMERICANA
}

Ability Of Dental Post Concentration In Killing Cockro Americana

Rasman $^{1}$, Asrudi $^{2}$

${ }^{1}$ Poltekkes Kemenkes Makassar

${ }^{2}$ Poltekkes Kemenkes Makassar

*) celluasrudi@gmail.com

\begin{abstract}
The cockroach is a beast of a bully who ate everything (omnivore), transmit diseases to humans. Cockroaches can transmit pathogens toxoplasma gondi and also carry salmonella and e. coli the efforts of controlling cockroaches using chemicals, namely toothpaste. The purpose of the research to know the ability of concentration variation of toothpaste in killing cockroaches. Type of this research is are descriptive. experiment this research was conducted in the laboratory of environmental health vector. The population in this research is the cockroach of Americana. Cockroach adult Americana which 30 samples of the tail on a jar filled 5 cockroach periplaneta Americana. The research shows the concentration of the ingredient toothpaste with 2, 4, 6, 8, 10, and 12 grams of the cockroach periplaneta Americana is capable of killing with a time less than an hour and effectively killed. Concentration of $2 \mathrm{gr}, 4 \mathrm{gr}, 6 \mathrm{gr}, 8 \mathrm{gr}, 10 \mathrm{gr}, 12 \mathrm{gr}$ and population can lose 100\% kocoa and the most effective concentration of 12 grams in 20 minutes. Based on the results of the study it can be concluded that the toothpaste that is dissolved in water $(100 \mathrm{ml})$ with different concentrations such as 2, 4, 6, 8, 10, and 12 grams can kill cockroaches periplaneta Americana. so it is expected that utilises toothpaste within easy reach in the lower population of cockroaches.
\end{abstract}

Key words:Concentration Of Toothpaste, Cockroaches, periplaneta Americana

\section{ABSTRAK}

Kecoa merupakan binatang pengganggu yang memakan segalanya (omnivore), menularkan penyakit pada manusia. Kecoa dapat menularkan patogen toxoplasma gondi dan juga membawa salmonella dan E.coli upaya pengendalian kecoa dengan menggunakan bahan kimia yaitu pasta gigi. Tujuan penelitian untuk mengetahui kemampuan variasi konsentrasi pasta gigi dalam membunuh kecoa. Jenis penelitian ini eksprimen yang bersipat deskriptif.penelitian ini dilakukan dilaboraterium vector kesehatan lingkungan. Populasi dalam penelitian ini adalah kecoa Americana. Kecoa Americana dewasa yang dijadikan sampel berjumlah 30 ekor pada satu toples terisi 5 kecoa periplaneta Americana. Hasil penelitian menujukkan bahan pasta gigi dengan konsentarsi 2, 4, 6, 8, 10 ,dan 12 gram mampu membunuh kecoa periplaneta Americana dengan waktu kurang dari 1 jam dan efektif membunuh. Konsentrasi 2 gram, 4 gram, 6 gram, 8 gram, 10 gram, dan 12 gram dapat menurunkan populasi kocoa $100 \%$ dan konsentasi paling efektif 12 gram dalam waktu 20 menit. Berdasarkan hasil penelitian dapat disimpulkan bahwa pasta gigi yang dilarutkan di dalam air (100 ml) dengan konsentrasi yang berbeda seperti 2, 4, 6, 8, 10, dan 12 gram dapat membunuh kecoa periplaneta Americana. sehingga diharapkan agar memanfaatkan bahan pasta gigi yang mudah dijangkau dalam menurunkan populasi kecoa.

Kata Kunci: Konsentrasi Pasta Gigi, Kecoa, periplaneta Americana

\section{PENDAHULUAN}

Masalah umum yang dihadapi dalam bidang kesehatan adalah jumlah penduduk yang besar dengan angka pertumbuhan yang cukup tinggi dan penyebaran penduduk yang belum merata, tingkat pendidikan dan sosial ekonomi yang masih rendah. Keadaan ini dapat menyebabkan lingkungan fisik dan biologis yang tidak memadai sehingga memungkinkan berkembang biaknya vektor penyakit. Salah satu vektor mekanik yang hidup berdampingan dengan manusia adalah kecoa. Kecoa merupakan serangga yang hidup di dalam rumah, restoran, hotel, rumah sakit, gudang, kantor, perpustakaan, dan lain-lain. Serangga ini sangat dekat kehidupannya dengan manusia, menyukai bangunan yang hangat, lembab, tempat yang banyak terdapat makanan, hidup secara berkelompok, dapat terbang, dan aktif pada malam hari seperti di dapur, di tempat penyimpanan makanan, sampah, saluran-saluran air kotor.

Umumnya kecoa menghindari cahaya, siang hari bersembunyi di tempat gelap dan sering bersembunyi di sela-sela bangunan. Serangga ini dikatakan pengganggu karena mereka biasa hidup ditempat kotor dan dalam keadaan terganggu mengeluarkan cairan yang berbau tidak sedap. Serangga ini dapat memindahkan beberapa mikroorganisme patogen antara lain Streptococcus, Salmonella dan lain-lain sehingga mereka berperan dalam penyebaran penyakit antara lain, tipus, toksoplasma, asma, disentri, diare, cholera, virus hepatitis A, polio pada anak-anak. Kecoak merupakan salah satu dari kelompok hama serangga. Kecoak merupakan organisme yang dapat berkembang dengan cepat karena adanya ketersediaan makanan dan kondisi lingkungan yang sesuai. Kecoak dapat hidup pada 
celah-celah di sekitar pembuangan limbah, dapur, tempat pembuangan sampah, gudang makanan dan lemari pakaian serta toilet (Nafis, 2009).

Kecoak sebagai hama pemukiman kini sudah tersebar di seluruh indonesia dan dapat beradaptasi pada lingkungan pemukiman manusia serta mampu berkembang biak dengan waktu yang singkat. Biasanya di tempat pemukiman, ditemukan di tempat-tempat yang hangat, lembab dan gelap. Ada beberapa jenis kecoa yang sering ditemukan, salah satunya adalah kecoak Jerman Blattella Germanica L. (Blattodea : Blattellidae) (Cornwell, 1968).

Pengendalian kecoak telah banyak dilakukan dengan berbagai cara, seperti secara kimiawi, sanitasi, biologis, atau mekanis (Enviromental Health Watch, 2005). Pada umumnya cara kimiawi lebih sering digunakan oleh masyarakat seperti penyemprotan, karena inilah yang paling praktis. Selain itu metoda ini dapat meninggalkan residu yang berbahaya bagi manusia. Karena seringnya dilakukan pemberian insektisida secara terusmenerus secara berkelanjutan, akibatnya dalam waktu jangka panjang akan menyebabkan terjadinya resistensi. Dimana kecoa tersebut dapat beradaptasi dan bertahan hidup dalam menghadapi berbagai tekanan seleksi (Ahmad, 2011).

Oleh karena, banyak orang yang menggunakan berbagai macam alat untuk membunuh kecoak, dimulai dari alat penangkap serangga sampai dengan bahan kimia yang berbahaya. Untuk itu, perlu adanya solusi membunuh kecoak tanpa harus mengeluarkan biaya yang besar dengan memanfaatkan sesuatu yang sering anda temukan di kamar mandi yaitu pasta gigi. Pasta gigi yang mengandung zat aktif seperti flourida, asam bicarbonate, dan baking soda. Di duga dapat digunakan sebagai bahan untuk membunuh kecoa dengan cara melarutkan pasta gigi dan menyemprotkan di bagian tubuh kecoa (Dr. Oz Indonesia, 2015)

Melihat uraian di atas peneliti tertarik membuat suatu penelitian dengan memperhatikan penggunaan dosis (gram) pasta gigi secara bertahap dan air yang konstan untuk menghitung berapa selang waktu (menit) yang dibutuhkan untuk membunuh kecoa secara efektif dan efisien.

\section{METODE PENELITIAN}

\section{Jenis Penelitian}

Jenis penelitian yang digunakan adalah eksperimen dengan pendekatan deskriptif, yaitu untuk mengetahui kemampuan pasta gigi dengan dosis yang berbeda dalam membunuh kecoa dengan melakukan 3 pengulangan.

\section{Lokasi Penelitian}

Adapun lokasi penelitian dilaksanakan di Laboratorium Politeknik Kesehatan, Makassar Jurusan Kesehatan Lingkungan.

\section{Waktu Penelitian}

Waktu penelitian dibagi menjadi dua tahap:

1. Tahap pertama yaitu tahap persiapan penelitian yang meliputi uji pendahuluan untuk menyusun proposal yang berlangsung pada bulan januari 2016 .

2. Tahap kedua yaitu tahap pelaksanaan penelitian yang dilakukan sekitar bulan april - mei 2016.

\section{Varibel Penelitian}

1. Variabel bebas yaitu pasta gigi dengan konsentrasi 2, 4, 6, 8, 10, dan 12 gram

2. Variabel terkait dalam hal ini waktu kematian kecoa periplaneta Americana.

3. Variabel pengganggu yaitu kelembaban.

\section{Definisi Operasional}

1. Kecoa adalah serangga pembawa penyakit dalam hal ini periplaneta Americana.

2. Konsentrasi pasta gigi yang dimaksud adalah jumlah pasta gigi 2, 4, 6, 8, 10, dan 12 gram yang digunakan dalam membunuh kecoa.

3. Lama pemajanan adalah rentang waktu yang digunakan mulai dari dimasukkannya kecoak kedalam wadah yang telah diberi insektisida hingga terjadi kematian pada kecoak selama 1 jam.

4. Kelembaban adalah konsentrasi uap air diudara yang diukurdengan menggunakan Higrometer.

5. Kematian kecoa adalah jumlah kecoa yang mati dalam waktu paparan dengan menggunakan pasta gigi.

\section{Kriteria Obyektif}

1. Penelitian dikatakan mampu apabila konsentrasi 2 gram, 4 gram, 6 gram, 8 
gram, 10 gram, dan 12 gram dapat memenuhi kriteria Lt artinya beberapa faktor percobaan yang mati dalam waktu 1 jam.

2. Penelitian dikatakan tidak mampu apabila konsentrasi 2 gram, 4 gram, 6 gram, 8 gram, 10 gram, dan 12 gram tidak dapat memenuhi kriteria Lt.

\section{Desain Penelitian}

Berdasarkan tujuan penelitian, yaitu untuk mengetahui kemampuan konsentrasi pasta gigi dalam membunuh kecoa. Jadi pada penelitian ini kecoa akan di paparkan atau diujikan dengan konsentrasi 2, 4, 6, 8, 10, dan 12 gram.

\section{Pengolahan dan analisis data}

Dijelaskan secara berurutan dalam bentuk paragraf, menggunakan huruf Arial 10 point dengan spasi 1 . Paragraf diawali dengan kata yang menjorok 6 digit ke dalam

\section{HASIL}

dalam menelitian kemampuan pasta gigi menggunakan alat sprayer dilaksanakan pada tanggal 9-12 Mei 2016 di laboratorium vektor kesehatan lingkungan, adapun jenis kecoa yang digunakan dalam penelitian yaitu kecoa periplaneta Americana, ukuran panjang kecoa 35-40 mm dan lebar 13-15 $\mathrm{mm}$, kecoa ini merupakan jenis paling besar dari semua kecoa. Bagian abdomen berwarna merah kecoklatan, pronotum berwarna kuning keruh degan dua bercak coklat di bagian tengahnya. Bagian belakang abdomen mempunyai sekrum yang relatif panjang, tipis dan runcing ujungnya seperti cemeti. Bahan pasta gigi yang di gunakan dalam penelitian ini yaitu pasta gigi dengan merek yang telah ditentukan oleh peneliti.

Hasil penelitian dengan menggunakan berbagai macam konsentrasi yaitu 2 gram, 4 gram, 6 gram, 8 gram, 10 gram, 12 gram, dengan pasta gigi yang dipaparkan dengan kecoa selama \pm satu jam dan diamati setiap 10 menit, dimana setiap wadah diberikan 5 ekor kecoa.

\section{Hasil Perlakuan Menggunakan Pasta Gigi Dengan Konsentrasi 2 gram}

Pada 10 menit setelah pemajanan dari percobaan dengan menggunakan konsentrasi 2 gram dan dengan jumlah 5 ekor kecoaperiplaneta Americana di dalam wadah yang sudah terlebih dahulu di semprot,tidak ada yang mati. Kecoa tersebut berkeliaran dengan lincah di dalam wadah. Setelah 20 menit sebanyak 1 ekor kecoa yang mati. Kecoa yang masih hidup tergeletak di dalam wadah dan kecoa tersebut tidak aktif lagi berkeliaran di dalam wadah. Setelah 30 menit kecoa yang mati bertambah sebanyak 1 ekor, adapun kecoa yang masih hidup dengan kondisi yang sama sebelumnya yaitu tergeletak di dalam wadah dan kecoa tersebut tidak aktif lagi berkeliaran. Setelah 40 menit berlalu bertambah $1 \quad$ kecoaperiplaneta Americanayang mati. Setelah 50 menit kecoa yang mati bertambah lagi sebanyak 1 ekor kecoa. Pada 60 menit dengan konsentrasi 2 gram pasta gigi, ada 1 ekor yang mati.

Tabel 1. Kemampuan pasta gigi dengan kosentrasi 2 gram dalam mematikan kecoa

\begin{tabular}{ccccc}
\hline No & Waktu & $\begin{array}{c}\text { Jumlah } \\
\text { sampel }\end{array}$ & $\begin{array}{c}\text { Jumlah Kecoa yang } \\
\text { Mati }\end{array}$ \\
\cline { 3 - 5 } $\mathbf{1}$ & $\begin{array}{c}10 \\
\text { menit }\end{array}$ & 5 & 0 & 0 \\
$\mathbf{2}$ & $\begin{array}{c}20 \\
\text { menit }\end{array}$ & 5 & 1 & 20 \\
$\mathbf{3}$ & $\begin{array}{c}30 \\
\text { menit }\end{array}$ & 5 & 1 & 20 \\
$\mathbf{4}$ & $\begin{array}{c}40 \\
\text { menit }\end{array}$ & 5 & 1 & 20 \\
$\mathbf{5}$ & $\begin{array}{c}50 \\
\text { menit } \\
60\end{array}$ & 5 & 1 & 20 \\
$\mathbf{6}$ & $\begin{array}{c}60 \\
\text { menit }\end{array}$ & 5 & 1 & 20 \\
\hline
\end{tabular}

\section{Hasil Perlakuan Menggunakan Pasta Gigi Dengan Konsentrasi 4 gram}

Pada 10 menit setelah pemajanan dari konsentasi 4 gram, kecoa tidak ada yang mati, dan kecoa lainnya masih aktif bergerak di dalam wadah. Setelah 20 menit berlalu 2ekor kecoa mati. Kecoa yang masih hidup dan masih berjalan di dalam wadah.setelah waktu 30 menit kecoa bertambah 1 ekor yang mati, kemudian kecoa yang masi hidup dengan kondisi yang sama, kemudian pada waktu 40 menit bertambah lagi 1 ekor kecoa yang mati, dan pada menit 50 bertambah 1 ekor kecoa yang mati. waktu yang dibutuhkan dalam membunuh kecoa periplaneta Americana pada konsentrasia 4 gram sebanyak 50 menit. 
Tabel 2. Kemampuan pasta gigi dengan kosentrasi 4 gram dalam mematikan kecoa

\begin{tabular}{ccccc}
\hline No & Waktu & $\begin{array}{c}\text { Jumlah } \\
\text { sampel }\end{array}$ & \multicolumn{2}{c}{$\begin{array}{c}\text { Jumlah kematian } \\
\text { kecoa }\end{array}$} \\
\cline { 3 - 5 } & & & 4 gram & $\begin{array}{c}\text { Kematian } \\
(\%)\end{array}$ \\
$\mathbf{1}$ & $\begin{array}{c}10 \\
\text { menit }\end{array}$ & 5 & 0 & 20 \\
$\mathbf{2}$ & $\begin{array}{c}20 \\
\text { menit }\end{array}$ & 5 & 2 & 40 \\
\hline $\mathbf{3}$ & $\begin{array}{c}30 \\
\text { menit }\end{array}$ & 5 & 1 & 20 \\
\hline $\mathbf{4}$ & $\begin{array}{c}40 \\
\text { menit }\end{array}$ & 5 & 1 & 20 \\
\hline $\mathbf{5}$ & $\begin{array}{c}50 \\
\text { menit }\end{array}$ & 5 & 1 & 20 \\
\hline $\mathbf{6}$ & $\begin{array}{c}60 \\
\text { menit }\end{array}$ & 5 & 0 & 0 \\
\hline & \multicolumn{2}{c}{ Total } & 5 & 100 \\
\hline
\end{tabular}

Hasil Perlakuan Menggunakan Pasta Gigi Dengan Konsentrasi 6 gram

Pada 10 menit setelah pemajanan dari konsentasi 6 gram, dengan menggunakan bahan pasta gigi dengan jumlah 5 ekor kecoaperiplaneta Americana di dalam wadah,sebanyak 1 ekor kecoa yang mati di dalam wadah. Adapun kecoa yang masih hidup sangat aktif berkeliaran. Setelah 20 menit bertambah 2 ekor kecoa yang mati, kecoa yang masih hidup ada yang bergeletak dan terdiam di tempatnya. Setelah 30 menit sebanyak 1 ekor kecoa yang mati, pada menit 40 bertambah 1 ekor kecoa yang mati, hal ini diuji sudah tidak ada yang tersisa.

Tabel 3. Kemampuan pasta gigi dengan kosentrasi 6 gram dalam mematikan kecoa

\begin{tabular}{|c|c|c|c|c|}
\hline \multirow[t]{2}{*}{ No } & \multirow[t]{2}{*}{ Waktu } & \multirow{2}{*}{$\begin{array}{l}\text { Jumlah } \\
\text { sampel }\end{array}$} & \multicolumn{2}{|c|}{$\begin{array}{l}\text { Jumlah kematian } \\
\text { kecoa }\end{array}$} \\
\hline & & & 6 gram & Kematian\% \\
\hline 1 & $\begin{array}{c}10 \\
\text { menit }\end{array}$ & 5 & 1 & 20 \\
\hline 2 & $\begin{array}{c}20 \\
\text { menit }\end{array}$ & 5 & 2 & 20 \\
\hline 3 & $\begin{array}{c}30 \\
\text { menit }\end{array}$ & 5 & 1 & 40 \\
\hline 4 & $\begin{array}{c}40 \\
\text { menit }\end{array}$ & 5 & 1 & 20 \\
\hline 5 & $\begin{array}{c}50 \\
\text { menit }\end{array}$ & 5 & 0 & 0 \\
\hline 6 & $\begin{array}{c}60 \\
\text { menit }\end{array}$ & 5 & 0 & 0 \\
\hline & \multicolumn{2}{|c|}{ Total } & 5 & 100 \\
\hline
\end{tabular}

\section{Hasil Perlakuan Menggunakan Pasta} Gigi Dengan Konsentrasi 8 gram

Pada 10 menit setelah pemajanan dari konsentrasi 8 gram, kecoa yang mati sebanyak 1 ekor, dan kecoa lainya masih aktif bergerak di dalam wadah yang sebelumnya sudah di semprotkan dengan bahan pasta gigi. Setelah waktu 20 menit bertambah 1 ekor kecoa yang mati, dan lama kemudian pada waktu 30 menit,bertambah 2 ekor kecoa yang mati dan tersisa tinggal 1 ekor kecoa, pada menit 40 bertambah 1 ekor kecoa yang mati.

Tabel 4. Kemampuan pasta gigi dengan kosentrasi 8 gram dalam mematikan kecoa

\begin{tabular}{ccccc}
\hline No & Waktu & $\begin{array}{c}\text { Jumlah } \\
\text { sampel }\end{array}$ & \multicolumn{2}{c}{$\begin{array}{c}\text { Jumlah kematian } \\
\text { kecoa }\end{array}$} \\
\cline { 4 - 5 } $\mathbf{1}$ & & & 8 gram & Kematian\% \\
\hline $\mathbf{2}$ & $\begin{array}{c}10 \\
\text { menit }\end{array}$ & 5 & 1 & 20 \\
$\mathbf{2 0}$ & 5 & 1 & 20 \\
$\mathbf{3}$ & $\begin{array}{c}30 \\
\text { menit }\end{array}$ & 5 & 2 & 40 \\
$\mathbf{4}$ & $\begin{array}{c}40 \\
\text { menit }\end{array}$ & 5 & 1 & 20 \\
$\mathbf{5}$ & $\begin{array}{c}50 \\
\text { menit }\end{array}$ & 5 & 0 & 0 \\
$\mathbf{6}$ & $\begin{array}{c}60 \\
\text { menit }\end{array}$ & 5 & 0 & 0 \\
\hline
\end{tabular}

Hasil Perlakuan Menggunakan Pasta Gigi Dengan Konsentrasi 10 gram

Pada konsentrasi 10 gram dengan menggunakan bahan pasta gigi yang sudah di larutkan dengan air sebanyak $100 \mathrm{ml}$, dengan jumlah 5 ekor kecoaperiplaneta Americana di dalam wadah, pada waktu 10 menit sebanyak 2 ekor kecoa yang mati. Adapun kecoa yang masih hidup sangat aktif berkeliaran dan berjalan. Setelah 20 menit bertambah 1 ekor kecoa yang mati, kecoa yang masih hidup ada yang bergeletak dan terdiam di tempatnya. Setelah 30 menit sebanyak 2 ekor kecoa yang mati, kecoa yang di uji sudah tidak ada yang tersisa. 
Tabel 5. Kemampuan pasta gigi dengan kosentrasi 10 gram dalam mematikan kecoa

\begin{tabular}{ccccc}
\hline No & Waktu & $\begin{array}{c}\text { Jumlah } \\
\text { sampel }\end{array}$ & \multicolumn{2}{c}{$\begin{array}{c}\text { Jumlah kematian } \\
\text { kecoa }\end{array}$} \\
\cline { 3 - 5 } & & & $\begin{array}{c}10 \\
\text { gram }\end{array}$ & Kematian\% \\
$\mathbf{1}$ & $\begin{array}{c}10 \\
\text { menit }\end{array}$ & 5 & 2 & 40 \\
$\mathbf{2}$ & $\begin{array}{c}20 \\
\text { menit }\end{array}$ & 5 & 1 & 20 \\
$\mathbf{3}$ & $\begin{array}{c}30 \\
\text { menit }\end{array}$ & 5 & 2 & 40 \\
$\mathbf{4}$ & $\begin{array}{c}40 \\
\text { menit }\end{array}$ & 5 & 0 & 0 \\
$\mathbf{5}$ & $\begin{array}{c}50 \\
\text { menit } \\
60\end{array}$ & 5 & 0 & 0 \\
$\mathbf{6}$ & $\begin{array}{c}6 \\
\text { menit }\end{array}$ & & 0 & 0 \\
\hline
\end{tabular}

\section{Hasil Perlakuan Menggunakan Pasta Gigi Dengan Konsentrasi 12 gram}

Pada 10 menit setelah pemajanan dari konsentasi 12 gram,kecoa periplaneta Americanayang mati sebanyak 2 ekor. kemudian kecoa yang lain masih berkeliaran, setelah itu kecoa yang tadinya berkeliaran, pada saat waktu 20 menit kecoa mati sebanyak 2 ekor, dan pada waktu 30 menit kecoa mati sebanyak 1 ekor, kecoa yang sudah diuji tidak tersisa. Setelah 30 menit pemajanan sudah tidak dilakukan lagi pengamatan disebabkan semua kecoa sudah mati dengan jangka waktu 30 menit.

Tabel 6. Kemampuan pasta gigi dengan kosentrasi 12 gram dalam mematikan kecoa

\begin{tabular}{|c|c|c|c|c|}
\hline \multirow[t]{2}{*}{ No } & \multirow[t]{2}{*}{ Waktu } & \multirow[t]{2}{*}{$\begin{array}{l}\text { Jumlah } \\
\text { sampel }\end{array}$} & \multicolumn{2}{|c|}{$\begin{array}{c}\text { Jumlah kecoa yang } \\
\text { mati }\end{array}$} \\
\hline & & & $\begin{array}{c}12 \\
\text { gram }\end{array}$ & Kematian\% \\
\hline 1 & $\begin{array}{c}10 \\
\text { menit }\end{array}$ & 5 & 2 & 40 \\
\hline 2 & $\begin{array}{c}20 \\
\text { menit }\end{array}$ & 5 & 2 & 40 \\
\hline 3 & $\begin{array}{c}30 \\
\text { menit }\end{array}$ & 5 & 1 & 20 \\
\hline 4 & $\begin{array}{c}40 \\
\text { menit }\end{array}$ & 5 & 0 & 0 \\
\hline 5 & $\begin{array}{c}50 \\
\text { menit }\end{array}$ & 5 & 0 & 0 \\
\hline 6 & $\begin{array}{c}60 \\
\text { menit }\end{array}$ & 5 & 0 & 0 \\
\hline \multicolumn{3}{|c|}{ Total } & 5 & 100 \\
\hline
\end{tabular}

\section{PEMBAHASAN}

Hasil penelitian yang telah dilakukan dengan menggunakan enam konsentrasi yaitu 2 gram ,4 gram, 6 gram, 8 gram, 10 gram, 12 gram dengan menggunkan bahan pasta gigi yang sudah dilarutkan dengan air sebanyak 100 gram, dan selama 60 menit pengamatan dengan interval waktu setiap 10 menit, diperoleh jumlah kecoa yang mati sebanyak 5 ekor, pada waktu paparan dengan interval 10 menit dan konsentrasi yang berbeda pula. Penelitian ini membuktikan bahwa penggunaan pasta gigi sebagai bahan yang dapat mematikan kecoa dan dapat memberikan pengaruh dalam menurunkan populasi kecoa.

\section{Kemampuan pasta gigi dalam mematikan kecoa dengan kosentrasi 2 gram}

Pada 10 menit setelah pemajanan dari percobaan dengan menggunakan konsentrasi 2 gram dan dengan jumlah 5 ekor kecoaperiplaneta Americana di dalam wadah yang sudah terlebih dahulu di semprot,tidak ada yang mati. Kecoa tersebut berkeliaran dengan lincah di dalam wadah. Setelah 20 menit sebanyak 1 ekor kecoa yang mati. Kecoa yang masih hidup tergeletak di dalam wadah dan kecoa tersebut tidak aktif lagi berkeliaran di dalam wadah. Setelah 30 menit kecoa yang mati bertambah sebanyak 1 ekor, adapun kecoa yang masih hidup dengan kondisi yang sama sebelumnya yaitu tergeletak di dalam wadah dan kecoa tersebut tidak aktif lagi berkeliaran. Setelah 40 menit berlalu bertambah $1 \quad$ kecoaperiplaneta Americanayang mati. Setelah 50 menit kecoa yang mati bertambah lagi sebanyak 1 ekor kecoa. Pada 60 menit dengan konsentrasi 2 gram pasta gigi, ada 1 ekor yang mati.

Setelah melakukan penelitian kemampuan pasta gigi dalam mengendalikan kecoa dengan konsentrasi 2 gram, lithel time (Lt) memenuhi kriteria efektif tercapai setelah 60 menit, kecoa yang mati mencapai 5 ekor pada 60 menit efektif dalam mematikan kecoa.

Kemampuan pasta gigi dalam mematikan kecoa dengan kosentrasi 4 gram

Pada 10 menit setelah pemajanan dari konsentasi 4 gram,kecoa tidak ada yang mati, dan kecoa lainnya masih aktif bergerak di dalam wadah. Setelah 20 menit 
berlalu 2 ekor kecoa mati. kecoa yang masih hidup dan masih berjalan di dalam wadah.setelah waktu 30 menit kecoa bertambah 1ekor yang mati,kemudian kecoa yang masi hidup dengan kondisi yang sama, kemudian pada waktu 40 menit bertambah lagi 1 ekor kecoa yang mati, dan pada menit 50 bertambah 1 ekor kecoa yang mati. waktu yang dibutuhkan dalam membunuh kecoa periplaneta Americana pada konsentrasia 4 gram sebanyak 50 menit, Setelah melakukan penelitian kemampuan pasta gigi dalam menggendalikan kecoa dengan konsentrasi 4 gram, lithel time $(L t)$ memenuhi kriteria membunuh tercapai,pada 50 menit dan dapat menurunkan populasi dengan jumlah kematian 5 ekor kecoa .

\section{Kemampuan pasta gigi dalam mematikan kecoa dengan kosentrasi 6 gram}

Pada 10 menit setelah pemajanan dari konsentasi 6 gram,dengan menggunakan bahan pasta gigi dengan jumlah 5 ekor kecoaperiplaneta Americana di dalam wadah, sebanyak 1 ekor kecoa yang mati di dalam wadah. Adapun kecoa yang masih hidup sangat aktif berkeliaran. Setelah 20 menit bertambah 2 ekor kecoa yang mati, kecoa yang masih hidup ada yang bergeletak dan terdiam di tempatnya. Setelah 30 menit sebanyak 1 ekor kecoa yang mati, pada menit 40 bertambah 1 ekor kecoa yang mati, hal ini diuji sudah tidak ada yang tersisa, Setelah melakukan penelitian kemampuan pasta gigi dalam menggendalikan kecoa dengan konsentrasi 6 gram, lithel time (Lt) memenuhi kriteria mampu membunuh kecoa yang paling bayak mati pada waktu 20 menit dengan jumlah 2 ekor.

\section{Kemampuan pasta gigi dalam mematikan kecoa dengan kosentrasi 8 gram}

Pada 10 menit setelah pemajanan dari konsentrasi 8 gram, kecoa yang mati sebanyak 1 ekor, dan kecoa lainya masih aktif bergerak di dalam wadah yang sebelumnya sudah di semprotkan dengan bahan pasta gigi. Setelah waktu 20 menit bertambah 1 ekor kecoa yang mati, dan lama kemudian pada waktu 30 menit, bertambah 2 ekor kecoa yang mati dan tersisa tinggal 1 ekor kecoa, pada menit 40 bertambah 1 ekor kecoa yang mati, Setelah melakukan penelitian kemampuan pasta gigi dalam menggendalikan kecoa dengan konsentrasi 8 gram, lithel time (Lt) memenuhi kriteria mampu membunuh tercapai,pada waktu 30 menit dan dapat menurunkan populasi kecoa dengan jumlah kematian 2 ekor.

\section{Kemampuan pasta gigi dalam mematikan kecoa dengan kosentrasi 10 gram}

Pada konsentrasi 10 gram dengan menggunakan bahan pasta gigi yang sudah di larutkan dengan air sebanyak $100 \mathrm{ml}$, dengan jumlah 5 ekor kecoaperiplaneta Americana di dalam toples, pada waktu 10 menit sebanyak 2 ekor kecoa yang mati. Adapun kecoa yang masih hidup sangat aktif berkeliaran dan berjalan. Setelah 20 menit bertambah 1 ekor kecoa yang mati, kecoa yang masih hidup ada yang bergeletak dan terdiam di tempatnya. Setelah 30 menit sebanyak 2 ekor kecoa yang mati, kecoa yang di uji sudah tidak ada yang tersisa. Setelah melakukan penelitian kemampuan pasta gigi dalam menggendalikan kecoa dengan konsentrasi 10 gram, lithel time (Lt) memenuhi kriteria mampu membunuh kecoa tercapai pada menit 10 dan menit 30 dengan jumlah kecoa yang mati sebanyak 2 ekor.

\section{Kemampuan pasta gigi dalam mematikan kecoa dengan kosentrasi 12 gram}

Pada 10 menit setelah pemajanan dari konsentasi 12 gram,kecoa periplaneta Americanayang mati sebanyak 2 ekor. kemudian kecoa yang lain masih berkeliaran, setelah itu kecoa yang tadinya berkeliaran, pada saat waktu 20 menit kecoa mati sebanyak 2 ekor, dan pada waktu 30 menit kecoa mati sebanyak 1 ekor, kecoa yang sudah diuji tidak tersisa. Setelah 30 menit pemajanan sudah tidak dilakukan lagi pengamatan disebabkan semua kecoa sudah mati dengan jangka waktu 30 menit,Setelah melakukan penelitian kemampuan pasta gigi dalam menggendalikan kecoa dengan konsentrasi 12 gram, lithel time (Lt) memenuhi kriteria mampu membunuh kecoa tercapai. Jumlah waktu yang dibutuhkan dalam membunuh kecoa sebanyak 30 menit, dengan konsentrasi 12 gram.

Penelitian ini dikatakan mampu dengan konsentrasi 2 gram, 4 gram, 6 
gram, 8 gram, 10 gram, 12 gram, dapat memenuhi kriteria Lt, semua kecoa mati dalam waktu kurang dari 1 jam. Kriteria mampu membunuh kecoa $90-100 \%$, pada konsentrasi yang berbeda dan tingkat waktu kematian kecoa yang berbeda.

Pada jumlah kematian kecoa dengan konsentrasi 2, 4, 6, 8, 10 dan 12 gram dengan waktu 10 menit kecoa mati mencapai 6 ekor, kemudian pada menit 20 kecoa mati sebanyak 9 ekor, pada menit 30 kecoa mati sebanyak 8 ekor, dan pada menit 40 kecoa mati sebanyak 4 ekor, pada menit 50 kecoa mati sebanyak 2 ekor, dan pada menit 60 kecoa mati sebanyak 1 ekor. Jadi semakin tinggi konsentrasi yang digunakan dalam penyemprotan semakin capat kematian kecoa dan dapat dilihat dari tabel 4.7. Dalam perbandingan 2 gram dengan kecepatan waktu 200 menit dapat membunuh kecoa sebanyak 9 ekor dan pada 12 gram dengan waktu 30 menit dapat membunuh kecoa sebanyak 1 ekor.

Penggunaan pasta gigi dapat mematikan kecoa itu dikarenakan kandungan di dalam pasta gigi biasanya terdiri dari Flouride, Asam bicarbonat, Baking Soda, Seperti diketahui bahwa Fluorida adalah senyawa kimia yang digunakan sebagai salah satu bahan untuk membuat pasta gigi. Senyawa ini dipercaya mampu memperkuat gigi, Senyawa fluorida juga dapat membunuh serangga seperti nyamuk, kecoak, dll.

Sementara itu Asam bikarbonate seperti diketahui merupakansenyawa kimia dengan rumus $\mathrm{NaHCo3}$. Dalam penyebutannya kerap disingkat menjadi bicnat. Senyawa ini termasuk kelompok garam dan telah digunakan sejak lama. Asam bikarbonat (soda kue) juga memiliki banyak manfaat salah satunya yaitu membunuh kecoa dengan cara campurkan dengan takaran sama ( 1:1 ) gula serpih (granulated sugar) dan soda kue dan letakkan di daerah yang sering dilewati kecoa.

Pengendalian kecoa telah banyak dilakukan dengan berbagai cara, seperti secara kimiawi, sanitasi, biologis, atau mekanis (Enviromental Health Watch, 2005).Pada umumnya cara kimiawi lebih sering digunakan oleh masyarakat seperti penyemprotan, karena inilah yang paling praktis. Selain itu metoda ini dapat meninggalkan residu yang berbahaya bagi manusia. Karena seringnya dilakukan pemberian insektisida secara terus- menerus secara berkelanjutan, akibatnya dalam waktu jangka panjang akan menyebabkan terjadinya resistensi. Dimana kecoa tersebut dapat beradaptasi dan bertahan hidup dalam menghadapi berbagai tekanan seleksi (Ahmad, 2011). Oleh karna itu, pengendalian kecoa dapat dilakukan dengan penggunaan pasta gigi yang mudah dijangkau, dan relatif aman bagi manusia, sehingga apabila diaplikasikan maka akan membunuh kecoa dan setelah kecoa terbunuh maka residunya cepat hilang di lingkungan.

\section{KESIMPULAN DAN SARAN}

\section{Kesimpulan}

1. Bahan pasta gigi dengan konsentrasi 2 gram mampu membunuh kecoa periplaneta Americana dengan jumlah 5 ekor dari 5 sampel yang diujikan dengan waktu 1 jam.

2. Bahan pasta gigi dengan konsentrasi 4 gram mampu membunuh kecoa periplaneta Americana dengan jumlah 5 ekor dari 5 sampel yang diujikan dengan waktu 50 menit.

3. Bahan pasta gigi dengan konsentrasi 6 gram mampu membunuh kecoa periplaneta Americana dengan jumlah 5 ekor dari 5 sampel yang diujikan dengan waktu 40 menit.

4. Bahan pasta gigi dengan konsentrasi 8 gram mampu membunuh kecoa periplaneta Americana dengan jumlah 5 ekor dari 5 sampel yang diujikan dengan waktu 40 menit.

5. Bahan pasta gigi dengan konsentrasi 10 gram mampu membunuh kecoa periplaneta Americana dengan jumlah 5 ekor dari 5 sampel yang diujikan dengan waktu 30 menit.

6. Bahan pasta gigi dengan konsentrasi 12 gram mampu membunuh kecoa periplaneta Americana dengan jumlah 5 ekor dari 5 sampel yang diujikan dengan waktu 30 menit.

\section{Saran}

1. Hasil penelitian ini diharapkan agar memanfaatkan bahan pasta gigi yang mudah dijangkau dan ramah lingkungan dalam menurunkan populasi kecoa.

2. Untuk penelitian selanjutnya dapat juga menggunakan salah satu bahan dari pasta gigi yaitu baking soda, florida, atau asam bikarbonat. 


\section{DAFTAR PUSTAKA}

Aang, 2012. Periplaneta americana. http://aangeifourend.com /2012/05/periplanetaamericana.html. Di akses pada tanggal 6 januari 2016.

Ahmad, I. 2011. Adaptasi Serangga dan Dampaknya Terhadap Kehidupan Manusia. Pidato IImiah Guru Besar ITB. Institut Teknologi Bandung. Di akses pada tanggal 2 januari 2016.

Anonim. 2011. Makalah vektor Kecoa. (Online).http://idhe-blok.blogspot.co.id/2011/10/makalahvektor-kecoa-klfkm-unhas-tahun.html (Diakses 5 Januari 2016).

Aryatie M.D, 2005. Pentingnya pemeliharaan kebersihan dan kesehatan dari vektor kecoa. www.she-cdivision.pdf. Di akses pada tanggal 6 januari 2016.

Cornwell, P.B. 1968. The Cockroach Vol 1, A Laboratory Insect and an Industrial Pest. London : Hutchinson. Di akses pada tanggal 2 januari 2016.

Enviromental Health Watch, 2005. Factsheet Cockroach Control Guide. Enviromental Health Watch. Di akses pada tanggal 2 januari 2016.

Hadi U.K, 2006. Lipas. Di dalam: Singgih HS dan Upik KH, editor. Hama Permukiman Indonesia: Pengenalan, Biologi, dan Pengendalian. Bogor : Unit Kajian Pengendalian Hama Permukiman, Fakultas Kedokteran Hewan, Institut Pertanian Bogor. Halaman 7378. Di akses pada tanggal 6 januari 2016.

Herdiana, 2012. Kengaruh Kecoa Terhadap Kesehatan. http://herdianaherman.wordpress.com/2012/05/29/pengaruh-kecoa-terhadapkesehatan.html. Di akses pada tanggal 6 januari 2016.

Hutabarat, R. 2009. Imigran-imigran Gelap yang Jago Terbang. http://rismahutabarat.blogspot.com/2009/06/imigran-imigran-gelap-yang-iagoterbang.html. di akses pada tanggal 6 januari 2016.

Jacobs, S.B. 2013.American Cockroaches. http://ento.psu.edu/extension/fact sheets/pdf/americancockroach.pdf.Di akses pada tanggal 2 januari 2016.

Kardinan, A. 2000. Pestisida nabati, Ramuan dan Aplikasi. Penebar Swadaya. Jakarta. Di akses pada tanggal 2 januari 2016.

Kompas, 2013. Aneh, Kecoa Ternyata Suka Menjilat Antenanya. Tersedia di http://internasional.kompas.com/read/2013/02/05/18585668/Aneh.Kecoa.Ternyata.Suka. Menjilat.Antenanya. Di akses pada tanggal 6 januari 2016.

Nafis. F, 2009. Persepsi Masyarakat Perkotaan Terhadap Hama Permukiman serta Pengujian Perangkap dan Pestisida Untuk Mengendalikan Tikus dan Kecoa. Pasca Sarjana Institut Pertanian Bogor : Bogor. Di akses pada tanggal 2 januari 2016.

Naria E, 2005. Insektisida Nabati Untuk Rumah Tangga. Departemen Kesehatan Lingkungan. Fakultas Kesehatan Masyarakat. Universitas Sumatra Utara, Medan. Di akses pada tanggal 2 januari 2016

Sulaiman, S., A.H. Muhammad., and H, Othman. 2007. Efficacy of Hydro methylnon and Fipronil Gel Baits with Laboratory and Field Strains of Pcriplancta americana (Dictyoptera:Blattelidae) in Malaysia. The Joumal ofTropical Medicine and Parasitology, 30 (2): 64-67. Di akses pada tanggal 2 januari 2016 